Terr. Atmos. Ocean. Sci., Vol. 17, No. 4, 679-702, December 2006

\title{
Geological Study of Active Cold Seeps in the Syn-Collision Accretionary Prism Kaoping Slope off SW Taiwan
}

\author{
Chi-Yue Huang ${ }^{1,2, *}$, Chih-Wei Chien ${ }^{1}$, Meixun Zhao ${ }^{3}$, Hong-Chun $\mathrm{Li}^{1,2}$, and Yoshiyuki lizuka ${ }^{4}$
}

(Manuscript received 24 March 2006, in final form 31 July 2006)

\begin{abstract}
Pogonophoran tube worms, elongated pyrite tubes and authigenic carbonate nodules are used to evaluate the occurrence of potential cold seeps in the syn-collision accretionary prism Kaoping Slope off SW Taiwan. At least two species of pogonophoran tubeworms were found in surface and core sediments. Pyrites occur in three different forms: fillings inside foraminiferal chambers, cements between calcareous microfossils, and elongated tubes. The bottom water off $\mathrm{SW}$ Taiwan is aerobic, but authigenic pyrites are found in the surface sediments at several sites, suggesting the existence of local reducing environments enabling the formation of pyrites. These environments are most likely caused by the occurrence of active cold seeps where methane expulses. Authigenic carbonates with highly depleted carbon isotope values (-54 to $-43 \%$ ) were found at more than 5 locations, in agreement with a methane-derived source for the carbon.

Integrating these geological and biological results, this study demonstrates that there are active cold seeps with methane expulsions in several anticline hinge zones east of the associated thrust faults in water depths of $800-1500 \mathrm{~m}$ of the frontal syn-collision accretionary prism Kaoping Slope. The existence of these high potential active cold seep sites is also supported by the occurrences of distinct bottom simulating reflectors (BSRs), shallow
\end{abstract}

\footnotetext{
1 Department of Earth Sciences, National Cheng Kung University, Tainan, Taiwan, ROC

2 Research Center of Ocean Environment and Technology, National Cheng Kung University, Tainan, Taiwan, ROC

${ }^{3}$ Sate Key Laboratory of Marine Geology, School of Ocean and Earth Sciences, Tongji University, Shanghai, China

${ }^{4}$ Institute of Earth Sciences, Academia Sinica, Taipei, Taiwan, ROC

* Corresponding author address: Prof. Chi-Yue Huang, Department of Earth Sciences, National Cheng Kung University, Tainan, Taiwan, ROC; E-mail: huangcy@mail.ncku.edu.tw
} 


\title{
sulfate-methane interface and high concentrations of dissolved methane in bottom water.
}

\author{
(Key words: Cold seep, Gas hydrate, Accretionary prism, \\ Authigenic carbonate, Offshore SW Taiwan)
}

\section{INTRODUCTION}

Methane expulsions from cold seeps, mud volcanoes and dissociations of gas hydrate have been commonly documented from both active and passive continental margins (Milkov 2000; Fleischer et al. 2001; Kvenvolden and Lorenson 2001; Dimitrov 2002). In favorable geological settings, methane generated by variable sources may migrate upward along geological fractures, especially faults in accretionary prisms (Kastner 2001). However, the expulsed methane could originate from dissociations of gas hydrate as in the Hydrate Ridge of the Cascadia accretionary prism off Oregon (Suess et al. 2001; Boetius and Suess 2004) or from hydrocarbon seeps as in the Gulf of Mexico (Kennicutt et al. 1985). Gas hydrate is the crystallized methane and water molecule formed under favorable conditions of low temperature and high pressure. It has been found in the permafrost of high latitude regions (Dallimore et al. 1999) and in marine sediments several hundred meters below the seafloor in low latitude regions as shown by the occurrence of BSRs (Milkov 2000), or even on the seafloor of the Cascadia accretionary prism off Oregon (Suess et al. 2001; Riedel et al. 2006) and the Gulf of Mexico (Roberts 2001). For the last decade, the study of gas hydrate and fluid venting in modern marine environments has become one of the hot topics of earth sciences not only for its energy potential in the near future (Dallimore et al. 1999), but also for understanding its climate role as the release of the greenhouse gas, methane, to the atmosphere could cause abrupt temperature increases like the Eocene/Paleocene thermal event (Katz et al. 1999). Massive methane release could also cause mass extinctions of marine fauna such as the event during the Jurassic (Kemp et al. 2005), and it may also cause geohazards such as mass wasting in slope environments (Vogt et al. 1999).

In modern marine environments, active cold seeps are commonly associated with the occurrences of pockmarkers on the seafloor, BSRs in seismic profiles, shallow SMI in sediment columns and high concentration of dissolved methane in bottom water (Borowski et al. 1999; Gay et al. 2006). However, there are other geological and biological features associated with methane expulsions: 1) the occurrence of chemosynthetic community including mollusks and tubeworms (Paull et al. 1985; Sibuet and Olu 1998); 2) the existence of authigenic pyrites in the sediments (Kohn et al. 1998; Hill et al. 2004; Riedel et al. 2006); and 3) the occurrence of chemically precipitated authigenic carbonates with depleted carbon isotope values (Hathaway and Degens 1969; Kulm et al. 1986; Paull et al. 1992; Lein 2004).

Intensive marine surveys were conducted in $2004-2005$ in the syn-collision accretionary prism of the Kaoping Slope (Fig. 1) to assess the gas hydrate potential offshore of SW Taiwan. Here we report the spatial occurrences of tubeworms, pyrites, and authigenic carbonates and their carbon isotopes in surface and core sediments. The preliminary results are discussed to assess the potential locations of active cold seeps, which may be related to gas hydrate dissociation in the deep sediments off SW Taiwan. 


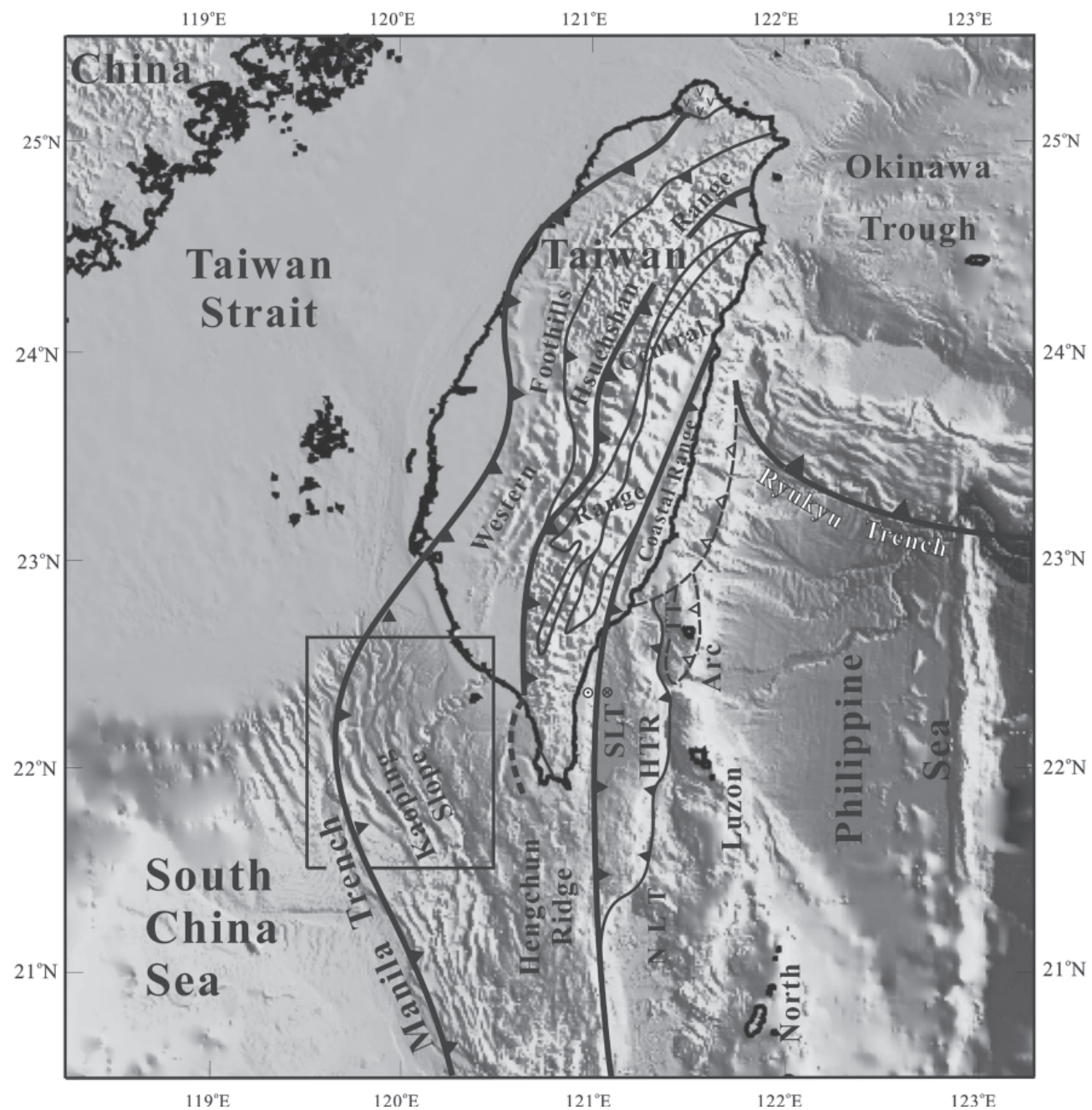

Fig. 1. Tectonic map of Taiwan showing the syn-collision accretionary prism of the Kaoping Slope off SW Taiwan (after Huang et al. 2006). The black square marks the study area.

\section{GEOLOGICAL SETTING AND STUDY METHODS}

The Kaoping Slope off SW Taiwan (Reed et al. 1992; Liu et al. 1998) represents the modern accretionary prism east of the Manila Trench (Fig. 1). This part of the accretionary 
prism has been developing since the latest Miocene during the collision between the Luzon arc of the Philippine Sea Plate and the Asian continental margin off SE Taiwan (Huang et al. 1997, 2000, 2006). The syn-collision accretionary prism is primarily composed of NW-trending folds and faults between the Manila Trench and the N-S-running pre-collision accretionary prism Hengchun Ridge (Fig. 1). The syn-collision accretionary prism changes its structural trend progressively from a NW-SE strike south of $22^{\circ} 15^{\prime} \mathrm{N}$ to a N-S/NNE-SSW direction when it approaches Taiwan (Fig. 1; Reed et al. 1992; Liu et al. 1993, 1998). This deformed offshore fold-and-thrust belt is finally exposed northward as the Western Foothills, southern Taiwan (Fig. 1). Mud diapir-like structures have been documented from the Kaoping Slope (Sun and Liu 1993; Chow et al. 2000; Chiu et al. 2006). Today, methane expulses from the mud volcanoes aligning in the NNE-SSW direction along the active thrust faults in the frontal Western Foothills on Taiwan (Shih 1967; Yang et al. 2004). For its geological continuity from the on-land Western Foothills to the offshore Kaoping Slope, it is highly conceivable that there could be some active mud volcanoes or cold seeps in the syn-collision accretionary prism Kaoping Slope off SW Taiwan.

More than 950 surface sediment samples and 49 cores (Table 1) collected from the Kaoping Slope in water depth ranging from 100 to $1500 \mathrm{~m}$ are used in this study (Fig. 2). Major faunal and mineralogical components of the sediments, such as foraminifers, tubeworms, mollusks, ostracods and pteropods, pyrites, gypsum and carbonate, are picked up from the washing residues ( $>150$ micron) of the frozen dry sediments for further study. Core top sediments are carefully checked to make sure whether they are preserved under aerobic condition, and are then cross-checked with the preservation state of foraminifers. The foraminifers in the core top sediments are generally shown by their brownish color on their test surfaces due to oxidation in an aerobic environment. The relative abundance of pyrite, foraminifers, tubeworm remains and authigenic carbonate nodules in each washing residue is verified semi-quantitatively under stereomicroscope $(\times 60)$.

The non-invasive LVSEM-EDS technique (JEOL JSM-6360LV SEM equipped with an EDS Oxford Instruments, INCA-300; Iizuka et al. 2005) is used to determine the chemical compositions of the metasoma segment of the pogonophoran tubeworms. Before SEM observation, samples were well cleaned with distilled water for several hours in an ultrasonic bath to remove dust and soil from their surfaces. Each sample was then rinsed in ethanol, and dried in an oven overnight at $75^{\circ} \mathrm{C}$ at the Institute of Earth Sciences, Academia Sinica in Taipei. The chemical composition of elements with amounts greater than $1 \%$ by weight was analyzed with a $1 \mu \mathrm{m}$ electron beam spot for 100 seconds. The quantitative data were corrected using the $\mathrm{x}$-ray intensities of synthetic minerals as standards.

Isotope analyses of carbonate samples were made in the Stable Isotope Laboratory of National Cheng Kung University (NCKU), Taiwan, using a Finnigan Delta XP mass spectrometer equipped with a Kiel III automatic device for sample loading. Each sample is placed in a reaction vial and five drops of $100 \% \mathrm{H}_{3} \mathrm{PO}_{4}$ were used for sample dissolution at $70^{\circ} \mathrm{C}$. The instrument has been calibrated with NBS-19, NBS-18 and LSVEC $\left(\mathrm{Li}_{2} \mathrm{CO}_{3}\right) .120$ measurements of NBS-19 show that the analytical precisions are $\pm 0.06 \%$ for $\delta^{18} \mathrm{O}$ and $\pm 0.04 \%$ for $\delta^{13} \mathrm{C}$ for $\sim 10 \mu \mathrm{g}$ sample size. For sample measurements, a working standard, Ultiss, is run for every 5 samples. All results are expressed against PDB. 
Table 1. Locations, type of cores, water depths and core lengths used in this study.

\begin{tabular}{|c|c|c|c|c|c|}
\hline Station & $\begin{array}{c}\text { Latitude } \\
(\mathrm{N})\end{array}$ & $\begin{array}{l}\text { Longitude } \\
\text { (E) }\end{array}$ & Coring method & $\begin{array}{c}\text { Water depth } \\
(\mathrm{m})\end{array}$ & $\begin{array}{c}\text { Length of core } \\
(\mathrm{cm})\end{array}$ \\
\hline 52 & $22^{\circ} 43.028^{\prime}$ & $119^{\circ} 52.850^{\prime}$ & $\mathrm{G}$ & 205 & 20 \\
\hline 50 & $22^{\circ} 36.492^{\prime}$ & $119^{\circ} 55.802^{\prime}$ & $\mathrm{G}$ & 540 & 80 \\
\hline 49 & $22^{\circ} 34.691^{\prime}$ & $11^{\circ} 55.982^{\prime}$ & $\mathrm{G}$ & 835 & 52 \\
\hline 48 & $22^{\circ} 33.025^{\prime}$ & $119^{\circ} 56.000^{\prime}$ & $\mathrm{G}$ & 1045 & 14 \\
\hline 47 & $22^{\circ} 28.832^{\prime}$ & $119^{\circ} 55.798^{\prime}$ & $\mathrm{G}$ & 1110 & 109 \\
\hline 46 & $22^{\circ} 36.025^{\prime}$ & $119^{\circ} 49.979^{\prime}$ & $\mathrm{G}$ & 694 & 80 \\
\hline 45 & $22^{\circ} 38.592^{\prime}$ & $119^{\circ} 49.265^{\prime}$ & $\mathrm{G}$ & 540 & 34 \\
\hline 33 & $22^{\circ} 37.423^{\prime}$ & $119^{\circ} 43.907^{\prime}$ & $G$ & 536 & 29 \\
\hline 32 & $22^{\circ} 36.104^{\prime}$ & $119^{\circ} 46.122^{\prime}$ & $G$ & 580 & 34 \\
\hline 31 & $22^{\circ} 34.436^{\prime}$ & $119^{\circ} 47.743^{\prime}$ & $\mathrm{G}$ & 900 & 87 \\
\hline 30 & $22^{\circ} 32.493^{\prime}$ & $119^{\circ} 40.810^{\prime}$ & $\mathrm{G}$ & 850 & 116 \\
\hline 29 & $22^{\circ} 27.859^{\prime}$ & $119^{\circ} 51.163^{\prime}$ & $\mathrm{G}$ & 1252 & 19 \\
\hline 28 & $22^{\circ} 26.630^{\prime}$ & $119^{\circ} 47.581^{\prime}$ & $\mathrm{G}$ & 1467 & 6 \\
\hline 27 & $22^{\circ} 23.643^{\prime}$ & $119^{\circ} 51.094^{\prime}$ & $G$ & 1213 & 123 \\
\hline 26 & $22^{\circ} 22.086^{\prime}$ & $119^{\circ} 51.029^{\prime}$ & $\mathrm{G}$ & 1297 & 22 \\
\hline 25 & $22^{\circ} 21.986^{\prime}$ & $119^{\circ} 53.799^{\prime}$ & $G$ & 1370 & 20 \\
\hline 24 & $22^{\circ} 25.737^{\prime}$ & $119^{\circ} 54.975^{\prime}$ & $\mathrm{G}$ & 1020 & 104 \\
\hline 23 & $22^{\circ} 25.316^{\prime}$ & $119^{\circ} 58.486^{\prime}$ & $\mathrm{G}$ & 760 & 109 \\
\hline 22 & $22^{\circ} 27.828^{\prime}$ & $120^{\circ} 00.925^{\prime}$ & $\mathrm{G}$ & 645 & 34 \\
\hline 21 & $22^{\circ} 30.551^{\prime}$ & $120^{\circ} 03.321^{\prime}$ & $\mathrm{G}$ & 490 & 102 \\
\hline 20 & $22^{\circ} 32.342^{\prime}$ & $120^{\circ} 06.875^{\prime}$ & $G$ & 290 & 20 \\
\hline 18 & $22^{\circ} 27.291^{\prime}$ & $120^{\circ} 06.625^{\prime}$ & $\mathrm{G}$ & 487 & 122 \\
\hline 17 & $22^{\circ} 24.845^{\prime}$ & $120^{\circ} 04.250^{\prime}$ & $\mathrm{G}$ & 686 & 102 \\
\hline 16 & $22^{\circ} 22.184^{\prime}$ & $120^{\circ} 02.290^{\prime}$ & $\mathrm{G}$ & 619 & 109 \\
\hline 15 & $22^{\circ} 19.448^{\prime}$ & $119^{\circ} 58.404^{\prime}$ & $\mathrm{G}$ & 970 & 123 \\
\hline 14 & $22^{\circ} 16.614^{\prime}$ & $119^{\circ} 55.448^{\prime}$ & $\mathrm{G}$ & 1100 & 123 \\
\hline G23 & $22^{\circ} 21.186^{\prime}$ & $119^{\circ} 48.909^{\prime}$ & $\mathrm{G}$ & 1229 & 27 \\
\hline G21 & $22^{\circ} 15.343^{\prime}$ & $119^{\circ} 52.919^{\prime}$ & $G$ & 1279 & 159 \\
\hline G19 & $22^{\circ} 17.343^{\prime}$ & $119^{\circ} 52.471^{\prime}$ & $\mathrm{G}$ & 1185 & 16 \\
\hline G15 & $22^{\circ} 18.790^{\prime}$ & $119^{\circ} 58.599^{\prime}$ & $\mathrm{G}$ & 990 & 34 \\
\hline G6 & $22^{\circ} 13.576^{\prime}$ & $119^{\circ} 57.019^{\prime}$ & $\mathrm{G}$ & 561 & 5 \\
\hline G5A & $22^{\circ} 09.307^{\prime}$ & $119^{\circ} 59.240^{\prime}$ & $\mathrm{G}$ & 1110 & 5 \\
\hline G3 & $22^{\circ} 08.474^{\prime}$ & $120^{\circ} 01.556^{\prime}$ & $\mathrm{G}$ & 1365 & 137 \\
\hline $\mathrm{D}$ & $22^{\circ} 13.235^{\prime}$ & $119^{\circ} 55.744^{\prime}$ & $\mathrm{G}$ & 1115 & 137 \\
\hline $\mathrm{C}$ & $22^{\circ} 14.801^{\prime}$ & $119^{\circ} 55.706^{\prime}$ & $G$ & 1166 & 102 \\
\hline $\mathrm{A}$ & $22^{\circ} 12.482^{\prime}$ & $119^{\circ} 58.404^{\prime}$ & $\mathrm{G}$ & 952 & 152 \\
\hline 111 & $22^{\circ} 15.237^{\prime}$ & $120^{\circ} 23.707^{\prime}$ & $\mathrm{G}$ & 223 & 66 \\
\hline 110 & $22^{\circ} 12.341^{\prime}$ & $120^{\circ} 20.424^{\prime}$ & $\mathrm{G}$ & 509 & 176 \\
\hline
\end{tabular}


Table 1. (Continued)

\begin{tabular}{|c|c|c|c|c|c|}
\hline Station & $\begin{array}{c}\text { Latitude } \\
(\mathrm{N})\end{array}$ & $\begin{array}{l}\text { Longitude } \\
\text { (E) }\end{array}$ & Coring method & $\begin{array}{c}\text { Water depth } \\
(\mathrm{m})\end{array}$ & $\begin{array}{l}\text { Length of core } \\
(\mathrm{cm})\end{array}$ \\
\hline 109 & $22^{\circ} 10.591^{\prime}$ & $120^{\circ} 18.845^{\prime}$ & $\mathrm{G}$ & 583 & 73 \\
\hline 108 & $22^{\circ} 09.053^{\prime}$ & $120^{\circ} 16.867^{\prime}$ & $\mathrm{G}$ & 772 & 27 \\
\hline 107 & $22^{\circ} 06.144^{\prime}$ & $120^{\circ} 13.962^{\prime}$ & $\mathrm{G}$ & 781 & 80 \\
\hline 105 & $22^{\circ} 02.943^{\prime}$ & $120^{\circ} 09.242^{\prime}$ & $\mathrm{G}$ & 919 & 145 \\
\hline 103 & $21^{\circ} 54.302^{\prime}$ & $120^{\circ} 13.340^{\prime}$ & G & 1500 & 173 \\
\hline 100 & $22^{\circ} 03.550^{\prime}$ & $120^{\circ} 25.508^{\prime}$ & $G$ & 679 & 20 \\
\hline 99 & $21^{\circ} 59.705^{\prime}$ & $120^{\circ} 20.314^{\prime}$ & $\mathrm{G}$ & 774 & 173 \\
\hline 96 & $22^{\circ} 11.067^{\prime}$ & $120^{\circ} 24.642^{\prime}$ & $\mathrm{G}$ & 407 & 130 \\
\hline 95 & $22^{\circ} 13.824^{\prime}$ & $120^{\circ} 26.594^{\prime}$ & $\mathrm{G}$ & 249 & 102 \\
\hline 94 & $22^{\circ} 08.830^{\prime}$ & $120^{\circ} 22.431^{\prime}$ & $G$ & 491 & 137 \\
\hline 93 & $22^{\circ} 07.078^{\prime}$ & $120^{\circ} 20.862^{\prime}$ & $G$ & 517 & 20 \\
\hline 92 & $22^{\circ} 03.912^{\prime}$ & $120^{\circ} 17.421^{\prime}$ & G & 785 & 34 \\
\hline 91 & $22^{\circ} 23.744^{\prime}$ & $120^{\circ} 13.049^{\prime}$ & $G$ & 369 & 109 \\
\hline 90 & $22^{\circ} 19.941^{\prime}$ & $120^{\circ} 07.851^{\prime}$ & $\mathrm{G}$ & 697 & 130 \\
\hline 89 & $22^{\circ} 22.033^{\prime}$ & $120^{\circ} 10.643^{\prime}$ & $\mathrm{G}$ & 493 & 116 \\
\hline 88 & $22^{\circ} 13.554^{\prime}$ & $120^{\circ} 14.538^{\prime}$ & $\mathrm{G}$ & 784 & 116 \\
\hline 87 & $22^{\circ} 18.128^{\prime}$ & $120^{\circ} 19.424^{\prime}$ & $\mathrm{G}$ & 204 & 123 \\
\hline 86 & $21^{\circ} 57.825^{\prime}$ & $120^{\circ} 08.795^{\prime}$ & $\mathrm{G}$ & 1366 & 87 \\
\hline 85 & $21^{\circ} 59.520^{\prime}$ & $120^{\circ} 10.781^{\prime}$ & G & 1324 & 150 \\
\hline 84 & $22^{\circ} 05.725^{\prime}$ & $120^{\circ} 03.213^{\prime}$ & $G$ & 1211 & 173 \\
\hline 82 & $22^{\circ} 11.940^{\prime}$ & $120^{\circ} 12.587^{\prime}$ & $\mathrm{G}$ & 839 & 116 \\
\hline 81 & $22^{\circ} 15.096^{\prime}$ & $120^{\circ} 16.321^{\prime}$ & $\mathrm{G}$ & 499 & 130 \\
\hline 73 & $22^{\circ} 07.859^{\prime}$ & $120^{\circ} 05.031^{\prime}$ & $\mathrm{G}$ & 945 & 87 \\
\hline 72 & $22^{\circ} 14.515^{\prime}$ & $120^{\circ} 01.342^{\prime}$ & G & 1004 & 123 \\
\hline 70 & $21^{\circ} 56.839^{\prime}$ & $120^{\circ} 16.983^{\prime}$ & $\mathrm{G}$ & 1045 & 173 \\
\hline 69 & $22^{\circ} 01.320^{\prime}$ & $120^{\circ} 13.239^{\prime}$ & $\mathrm{G}$ & 972 & 173 \\
\hline 67 & $22^{\circ} 16.893^{\prime}$ & $120^{\circ} 05.375^{\prime}$ & $\mathrm{G}$ & 765 & 12 \\
\hline N1 & $22^{\circ} 05.30^{\prime}$ & $119^{\circ} 59.37$ & $\mathrm{~B}$ & 1082 & $10 \mathrm{~cm}$ \\
\hline N4 & $22^{\circ} 11.14^{\prime}$ & $119^{\circ} 58.61$ & B & 983 & $41 \mathrm{~cm}$ \\
\hline N5 & $22^{\circ} 16.23^{\prime}$ & $119^{\circ} 51.84$ & $\mathrm{~B}$ & 932 & $11 \mathrm{~cm}$ \\
\hline N6 & $22^{\circ} 17.79^{\prime}$ & $119^{\circ} 53.22$ & $\mathrm{~B}$ & 1163 & $33 \mathrm{~cm}$ \\
\hline N9 & $22^{\circ} 17.01^{\prime}$ & $120^{\circ} 00.83$ & $\mathrm{~B}$ & 963 & $44 \mathrm{~cm}$ \\
\hline G4 & $22^{\circ} 08.84^{\prime}$ & $119^{\circ} 59.69$ & $\mathrm{~B}$ & 1061 & $36 \mathrm{~cm}$ \\
\hline G14 & $22^{\circ} 18.68^{\prime}$ & $119^{\circ} 58.72$ & $\mathrm{~B}$ & 1052 & $20 \mathrm{~cm}$ \\
\hline G16 & $22^{\circ} 20.90^{\prime}$ & $119^{\circ} 58.81$ & $\mathrm{~B}$ & 1076 & $20 \mathrm{~cm}$ \\
\hline G18 & $22^{\circ} 18.79^{\prime}$ & $119^{\circ} 55.22$ & B & 1217 & $22 \mathrm{~cm}$ \\
\hline $\mathrm{G} 22$ & $22^{\circ} 15.61^{\prime}$ & $119^{\circ} 51.08$ & $\mathrm{~B}$ & 1101 & $22 \mathrm{~cm}$ \\
\hline G24 & $22^{\circ} 21.53^{\prime}$ & $119^{\circ} 48.48$ & $\mathrm{~B}$ & 1098 & $16 \mathrm{~cm}$ \\
\hline
\end{tabular}

G: Gravity core; B: Box core. 
Table 1. (Continued)

\begin{tabular}{|c|c|c|c|c|c|}
\hline Station & $\begin{array}{c}\text { Latitude } \\
(\mathrm{N})\end{array}$ & $\begin{array}{c}\text { Longitude } \\
\text { (E) }\end{array}$ & $\begin{array}{l}\text { Coring } \\
\text { method }\end{array}$ & $\begin{array}{c}\text { Water depth } \\
(\mathrm{m})\end{array}$ & $\begin{array}{c}\text { Length of core } \\
(\mathrm{cm})\end{array}$ \\
\hline OD5-P3(GH-3) & $22^{\circ} 16.79^{\prime}$ & $119^{\circ} 48.58$ & $\mathrm{P}$ & 1671 & $3.4 \mathrm{~m}$ \\
\hline OD5-BOX(GH-3) & $22^{\circ} 16.80^{\prime}$ & $119^{\circ} 48.57$ & $\mathrm{P}$ & 1660 & \\
\hline OD2-P1(GH-6) & $22^{\circ} 20.14^{\prime}$ & $119^{\circ} 48.52$ & $\mathrm{P}$ & 1319 & \\
\hline C1-P (GH-7) & $22^{\circ} 28.47^{\prime}$ & $119^{\circ} 49.98$ & $\mathrm{P}$ & 927 & $235 \mathrm{~cm}$ \\
\hline C20-P1 (GH-8) & $22^{\circ} 31.95^{\prime}$ & $119^{\circ} 51.75$ & $\mathrm{P}$ & 1088 & $415 \mathrm{~cm}$ \\
\hline T12-P (GH-11) & $22^{\circ} 09.39^{\prime}$ & $119^{\circ} 46.13$ & $\mathrm{P}$ & 1487 & $455 \mathrm{~cm}$ \\
\hline C14-P (GH-13) & $22^{\circ} 04.94^{\prime}$ & $119^{\circ} 47.42$ & $\mathrm{P}$ & 1668 & $420 \mathrm{~cm}$ \\
\hline 19-P (GH-14) & $22^{\circ} 01.92^{\prime}$ & $119^{\circ} 50.98$ & $\mathrm{P}$ & 1649 & $450 \mathrm{~cm}$ \\
\hline C7-P (GH-15) & $22^{\circ} 05.83^{\prime}$ & $119^{\circ} 51.89$ & $\mathrm{P}$ & 1353 & $435 \mathrm{~cm}$ \\
\hline C9 (GH-18) & $21^{\circ} 50.25^{\prime}$ & $120^{\circ} 07.28$ & $\mathrm{P}$ & 1762 & $450 \mathrm{~cm}$ \\
\hline C8-P (GH-19) & $21^{\circ} 49.94^{\prime}$ & $120^{\circ} 07.70$ & $\mathrm{P}$ & 1756 & $430 \mathrm{~cm}$ \\
\hline HL-P1 (GH-20) & $22^{\circ} 13.16^{\prime}$ & $120^{\circ} 10.24$ & $\mathrm{P}$ & 1020 & $447 \mathrm{~cm}$ \\
\hline MD052911(G22) & $22^{\circ} 15.61^{\prime}$ & $119^{\circ} 51.08$ & MD & 1076 & $2389 \mathrm{~cm}$ \\
\hline MD052912 (G24) & $22^{\circ} 21.53$ & $119^{\circ} 48.48$ & $\mathrm{MD}$ & 1096 & $3044 \mathrm{~cm}$ \\
\hline MD052913 (G5a) & $22^{\circ} 09.40^{\prime}$ & $119^{\circ} 58.97$ & $\mathrm{MD}$ & 1096 & $1268 \mathrm{~cm}$ \\
\hline
\end{tabular}

P: Piston core; MD: giant piston core by $R / V$ Mariou Dufrense.

\section{RESULTS}

\subsection{Occurrences of Pogonophoran Worm Tubes}

Pogonophoran and vestimentiferan tubeworms are characteristic chemosynthetic community organisms living in cold seep and in hydrothermal smoker regions (Southward et al. 1981; Kulm et al. 1986; Dando et al. 1994; Sibuet and Olu 1998; Fleischer et al. 2001). They lack mouth and internal digestive system (Ivanov 1963; Jones 1985), indicating that these tubeworms must host some chemoautotrophic bacteria and are thereby fed on energy released by the oxidation of sulfides or methane (Southward et al. 1981; Felbeck 1981; Schmaljohann and Flügel 1987; Scott and Fisher 1995). They live commonly in abyssal plains ( $>3000 \mathrm{~m}$ ), but some species can live at littoral depth (Ivanov 1963). Tubeworm of Pogonophora is composed of three segments: protosoma, mesosoma and metasoma. The remains of Pogonophora, especially its relatively soft potosoma and mesosoma, are not well preserved in sediments after death due to the relatively quick decomposition of chitin. In comparison, the carbonate metasoma of vestimentiferan can be preserved in marine sediments, especially those encrusted on hard grounds like authigenic carbonates (Goedert et al. 2000). 


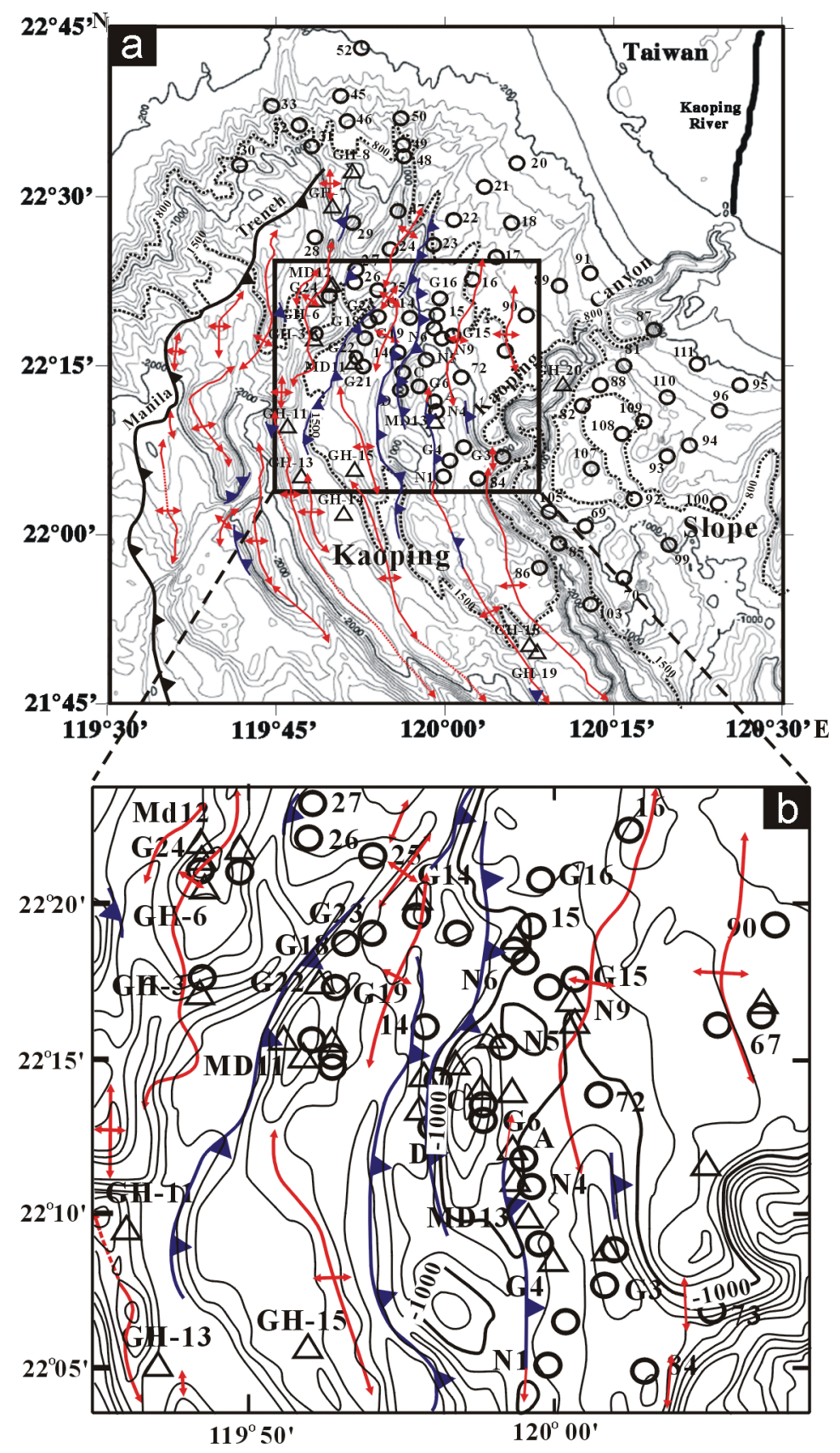

Fig. 2. Sampling localities for this study. Circles ( O ) are box core sites and triangles $(\Delta)$ are piston core sites. The detail of the square area in (a) is shown in (b). 
The morphology of metasoma suggests that there are at least two distinct species of Pogonophora in the study area (Fig. 3). Species A (Fig. 3a) and species B (Fig. 3b) are characterized by a soft, light brown metasoma tube without any ring in the former (Fig. 3a) but with distinct regular rings in the latter (Fig. 3b). The composition of the metasoma of both species is non-calcareous (Fig. 4), and is suggested to be made of chitin. In addition, a peculiar and unidentified organism (Figs. 3c, d) with a relatively hard, whitish metasoma tube with short spines in the outer surface of the tube was found in some samples. Both the metasoma and the spines are calcareous as revealed by EDS analyses (Fig. 5).

In the Kaoping Slope, remains of Pogonophora are found in the surface sediment sites of water depths ranging from 800 to $1500 \mathrm{~m}$, with the exception of one site (Fig. 6). Although the pogonophoran remains are found in sites both east and west of the submarine Kaoping Canyon, most of the sites are concentrated west of the Kaoping Canyon. Pogonophoran remains are unusually abundant at Station G24 (Fig. 3e).

\subsection{Occurrences of Pyrite Tubes}

On the ocean floor, when methane expulses, sulfate reduction and anaerobic methane oxidation result in the formation of $\mathrm{HS}^{-}$and $\mathrm{H}_{2} \mathrm{~S}$ (Eqs. 1, 2), and the sulfides further react with iron oxides in pore water to form $\mathrm{FeS}$ and $\mathrm{Fe}_{3} \mathrm{~S}_{4}$, and finally $\mathrm{FeS}_{2}$ (Eqs. 3, 4, and 5). Sulfate reduction:

$$
2\left(\mathrm{CH}_{2} \mathrm{O}\right)+\mathrm{SO}_{4}^{-2} \rightarrow 2 \mathrm{HCO}_{3}^{-}+\mathrm{H}_{2} \mathrm{~S},
$$

Anaerobic methane oxidation:

$$
\mathrm{CH}_{4}+\mathrm{SO}_{4}^{-2} \rightarrow \mathrm{HCO}_{3}^{-}+\mathrm{HS}^{-}+\mathrm{H}_{2} \mathrm{O}
$$

Formation of pyrite:

$$
\begin{aligned}
& 2 \mathrm{FeOOH}+3 \mathrm{H}_{2} \mathrm{~S} \rightarrow 2 \mathrm{FeS}+\mathrm{S}^{0}+4 \mathrm{H}_{2} \mathrm{O}, \\
& 3 \mathrm{FeS}+\mathrm{S}^{0} \rightarrow \mathrm{Fe}_{3} \mathrm{~S}_{4}, \\
& \mathrm{Fe}_{3} \mathrm{~S}_{4}+2 \mathrm{~S}^{0} \rightarrow 3 \mathrm{FeS}_{2} .
\end{aligned}
$$

Off SW Taiwan, authigenic pyrites appear in three different occurrences: (I) fillings within foraminiferal chambers or replacements of molluscan shells (I in Fig. 7a); (II) as cements between calcareous microfossils or molluscan fragments (II in Fig. 7a); and (III) formation of elongated tubes (III in Fig. 7a). The pyrite tubes, $2-3 \mathrm{~cm}$ in length and $0.2-0.3 \mathrm{~cm}$ in width are porous in the center and outer surfaces (Figs. $7 \mathrm{~b}, \mathrm{c}$ ). Similar elongated pyrite tubes are also found in the Hydrate Ridge of the Cascadia accretionary wedge off Oregon where dissociation and formation of gas hydrate on the seafloor display contemporaneously (Suess et al. 2001), and in the Dongsha area of the northern slope of the South China Sea, where active cold seeps have been suggested (Chen et al. 2005). 

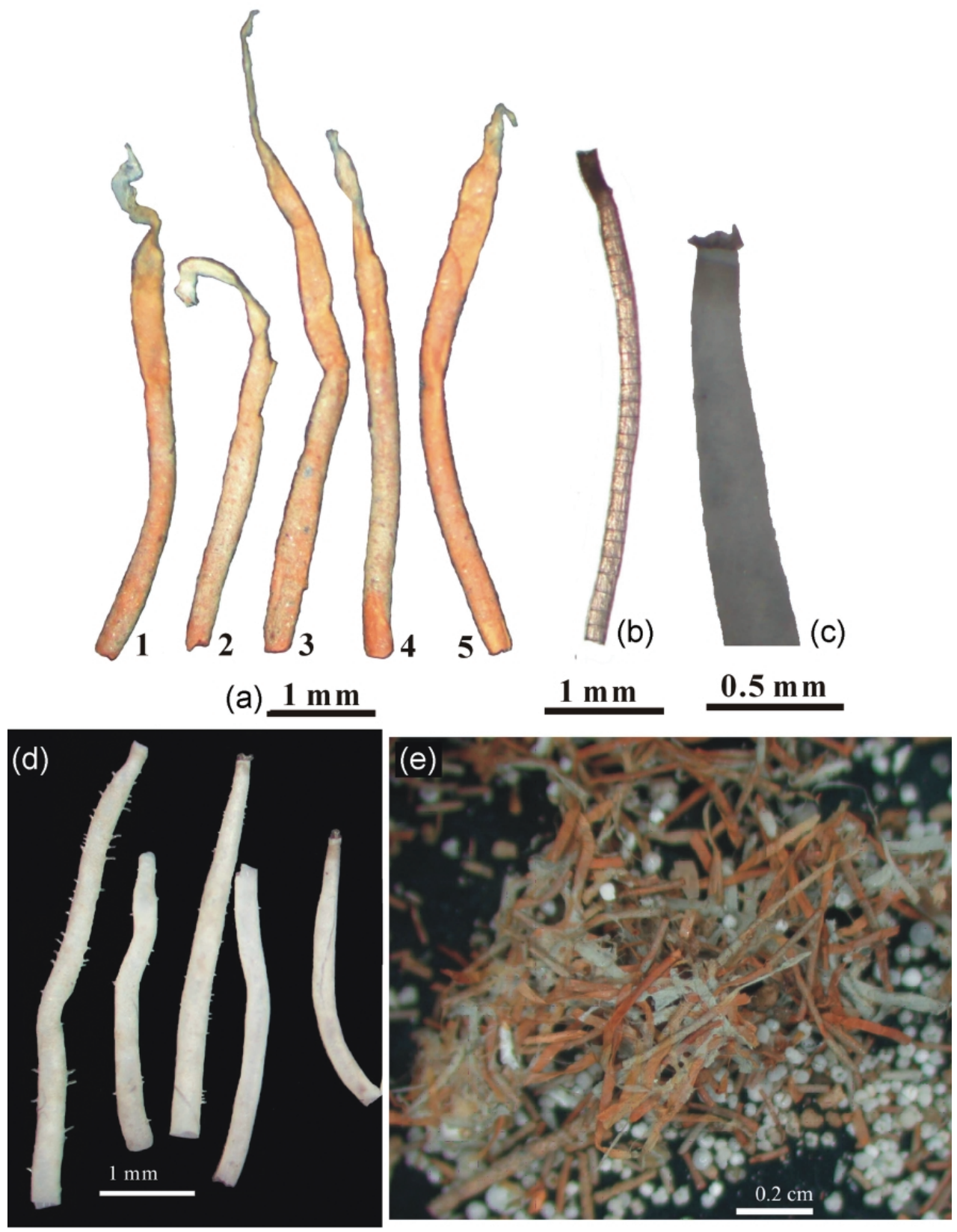

Fig. 3. Tubeworms of Pogonophora found in the surface sediments off SW Taiwan; (a) five specimens (1 5) of Species A without regular ring in metasoma; (b) Species B with regular rings in metasoma; (c, d) unknown species of Pogonophora; (e) abundant specimens of Species A in core G$24,2-4 \mathrm{~cm}$. 

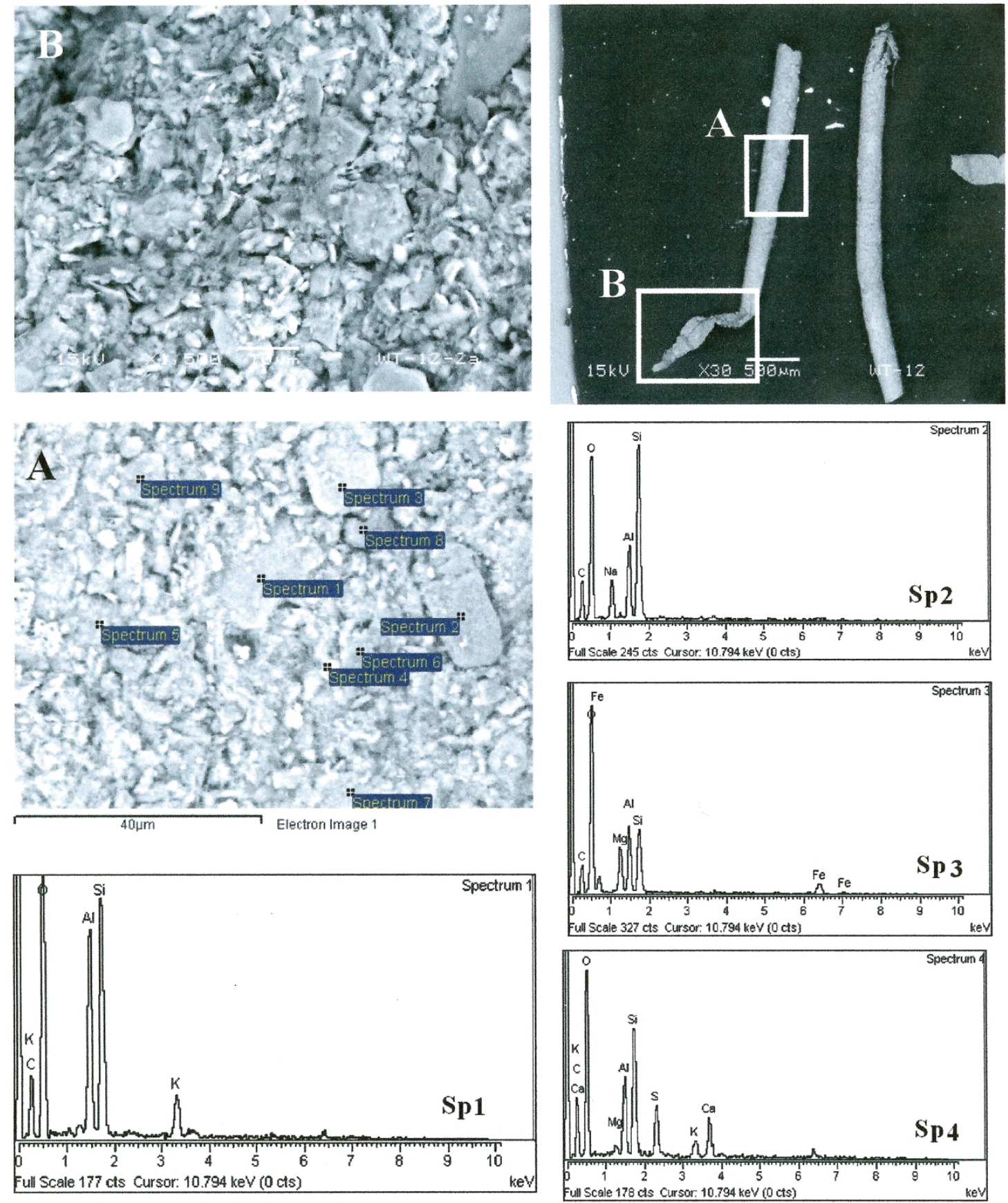

Fig. 4. EDS measurement of the chemical composition of the metasoma of type A Pogonophora. It reveals the lack of $\mathrm{CaCO}_{3}$ in the hard part. 

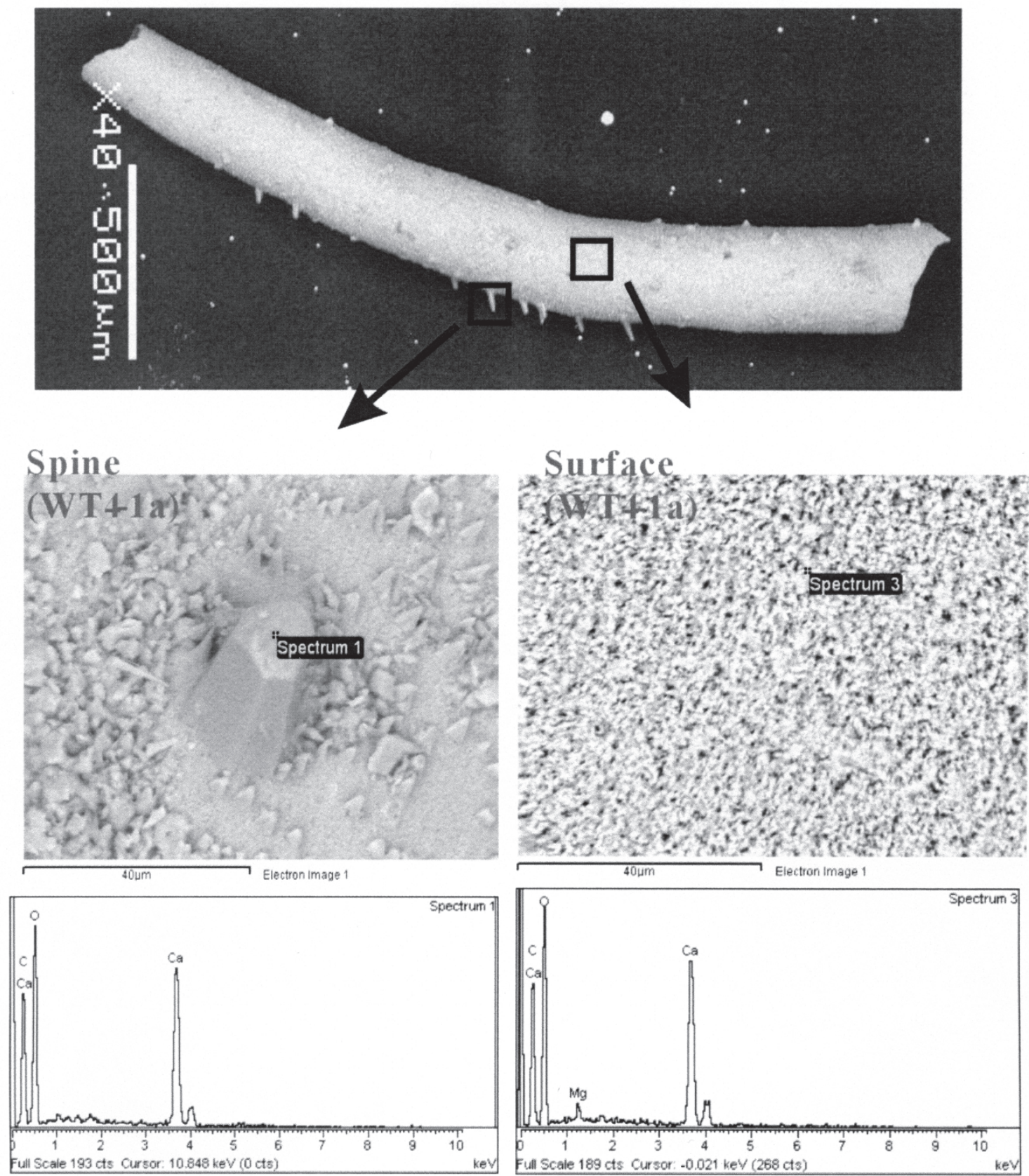

Fig. 5. EDS measurement of the chemical composition of the metasoma and the spine of type $\mathrm{C}$ Pogonophora. Both are made of $\mathrm{CaCO}_{3}$. 


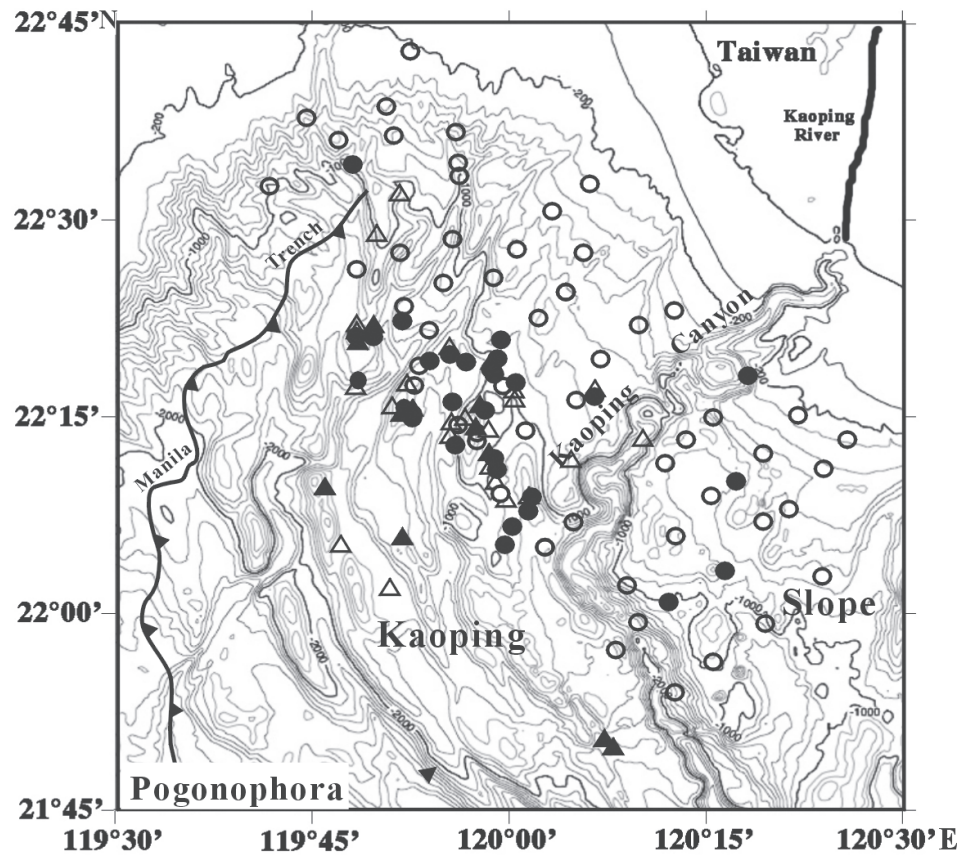

Fig. 6. Distribution of Pogonophora in the surface sediments of the study area. Filled circles $(\bullet)$ are box core sites and filled triangles $(\boldsymbol{\Delta})$ are piston core sites.
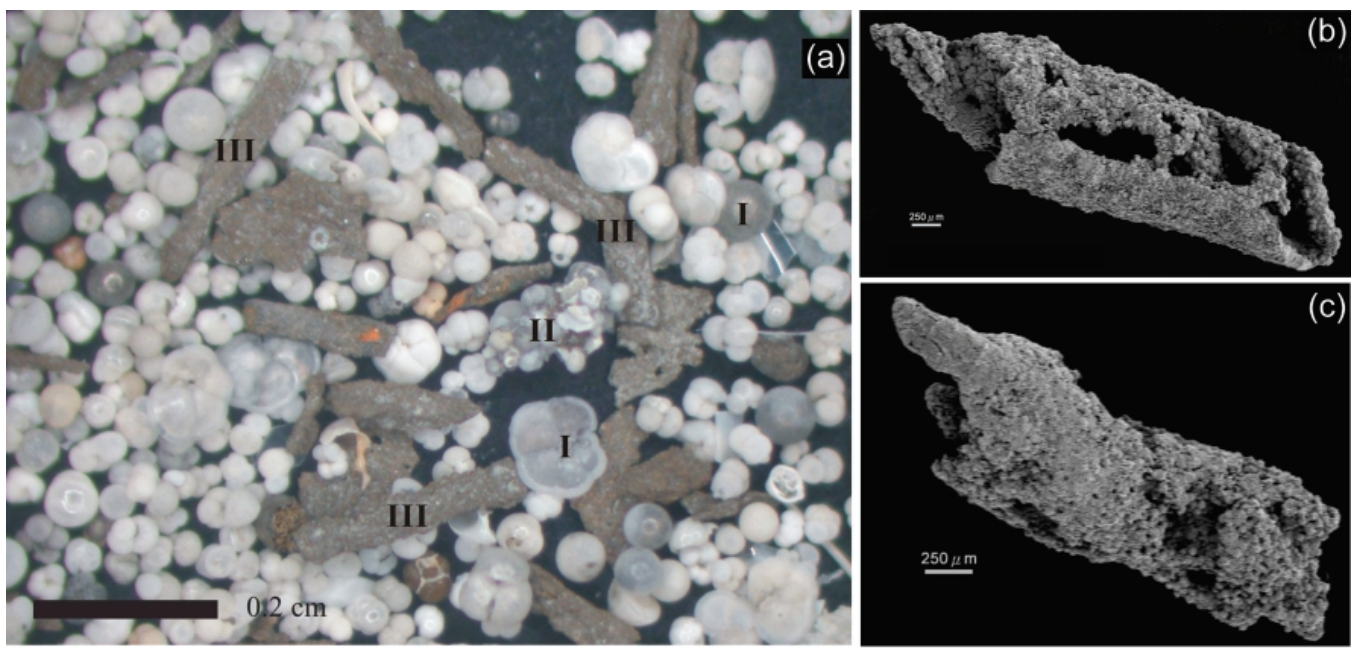

Fig. 7. (a) Types of pyrites identified in sediments off SW Taiwan: (I) As filling within foraminiferal chambers; (II) As cementation among foraminiferal tests; and (III) elongated tubes. (b, c) SEM images of the porous pyrite tubes in surface sediments (G17-B5; 2 - $4 \mathrm{~cm})$ off SW Taiwan. 
The authigenic pyrites occur in surface sediments of sites with water depths greater than $800 \mathrm{~m}$ (Fig. 8) and in down-core sediments of various depths for many cores (Fig. 9). Among them, the occurrence of pyrite tubes in the surface sediments (Fig. 8) is especially significant in assessing the potential locations of cold seeps because pyrites can be formed only under reducing condition. Since the bottom water off SW Taiwan is aerobic with dissolved oxygen content (DO) of $100 \mu \mathrm{M}$ at the DO minimum depth of $800-1000 \mathrm{~m}$ and $120 \mu \mathrm{M}$ at $2200 \mathrm{~m}$ (Lin et al. 1999), there must exist local reducing environments on the sediment surface to enable the chemical reactions for the formation of pyrites. Such local reducing environments are likely created from expulsions of methane from the deep sediments along some geological fractures such as faults. For both surface and subsurface sediments, elongated pyrite tubes are abundant in cores west of the Kaoping Canyon in water depths of 1000 - $1500 \mathrm{~m}$ (Fig. 9). They are especially abundant in cores G22P and MD052911, while the latter core also contains authigenic carbonate nodules in the deeper section (Fig. 10).

\subsection{Occurrences of Authigenic Carbonate Nodules}

In cold seep sites, sulfate reduction and oxidation of methane under anaerobic conditions would result in the formation of bicarbonate (Eqs. 1,2). Bicarbonate then reacts with calcium ions in porewater or seawater to precipitate authigenic carbonate in the upper part of the sediment column as carbonate nodules or carbonate pavements (Eq. 6):

$$
2 \mathrm{HCO}_{3}^{-}+\mathrm{Ca}^{+2} \rightarrow \mathrm{CaCO}_{3}+\mathrm{H}_{2} \mathrm{O}+\mathrm{CO}_{2}
$$

The chemical precipitation of carbonate is also closely related to microbial activity (Valentine 2002). Since the carbon in the authigenic carbonates is mainly derived from methane of either biogenic or thermogenic origin, the carbon isotope values of the authigenic carbonate is highly depleted (-100 -30\%; Hathaway and Degens 1969; Lein 2004). The occurrence of authigenic carbonates with low $\delta^{13} \mathrm{C}$ values thus becomes one of the best indicators to assess the potential site of cold seeps.

Authigenic carbonate nodules were found in surface and subsurface sediments of 5 sites in water depths of $800-1500 \mathrm{~m}$ off SW Taiwan (Fig. 11). These authigenic carbonate nodules are characterized by: 1) irregular shapes and sizes; 2) whitish color; 3) fine micrite; 4) minor content of dolomite, pyrite and elemental sulfur; 5) absence of visible mega-fossils; 6) occurrences of open voids; and 7) depleted carbon isotope values (Fig. 12).

In the giant piston core MD052911 (22 $2^{\circ} 15.617^{\prime} \mathrm{N}, 119^{\circ} 51.079^{\prime} \mathrm{E}$, water depth $\left.1076 \mathrm{~m}\right)$, authigenic carbonate nodules were recovered at core depths between 20 and $25 \mathrm{~m}$ (Fig. 10). Carbon isotope values of these authigenic carbonate nodules are highly depleted with values between -54 and $-46 \%$ (Table 2). Similar depleted carbon isotope values were also found in samples of core T8 $\left(22^{\circ} 04.48^{\prime} \mathrm{N}, 119^{\circ} 58.76^{\prime} \mathrm{E}\right.$; water depth $\left.930 \mathrm{~m} ; \delta^{13} \mathrm{C}:-48.06 \%\right)$, GH-16 (or T6-P; $22^{\circ} 06.69^{\prime} \mathrm{N}, 119^{\circ} 59.12^{\prime} \mathrm{E}$; water depth $1019 \mathrm{~m} ; \delta^{13} \mathrm{C}$ : $-53.48 \sim-57.60 \%$ ), and $108 \mathrm{G}$ $\left(22^{\circ} 09.053^{\prime} \mathrm{N}, 120^{\circ} 16.867{ }^{\prime} \mathrm{E}\right.$; water depth $772 \mathrm{~m}, \delta^{13} \mathrm{C}:-36.62 \%$; Table 2$)$, all suggesting a methane source of carbon. Local hard grounds of carbonate pavement might exist on the seafloor at these three stations, therefore the piston cores cannot penetrate much into the sediments and only a few carbonate nodules on the seafloor were recovered in core catchers. 


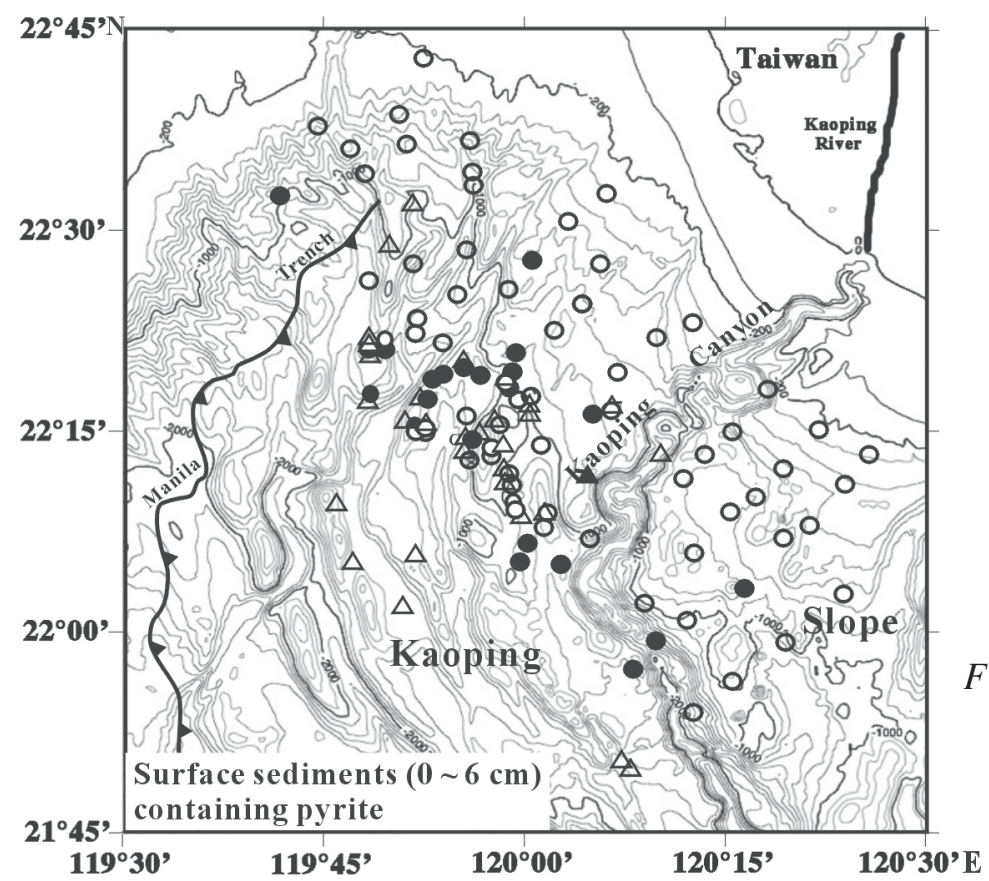

Fig. 8. Distribution of pyrite tubes in surface sediments $(0$ to $6 \mathrm{~cm})$ of box cores ( $)$ and piston cores $(\boldsymbol{\Delta})$.

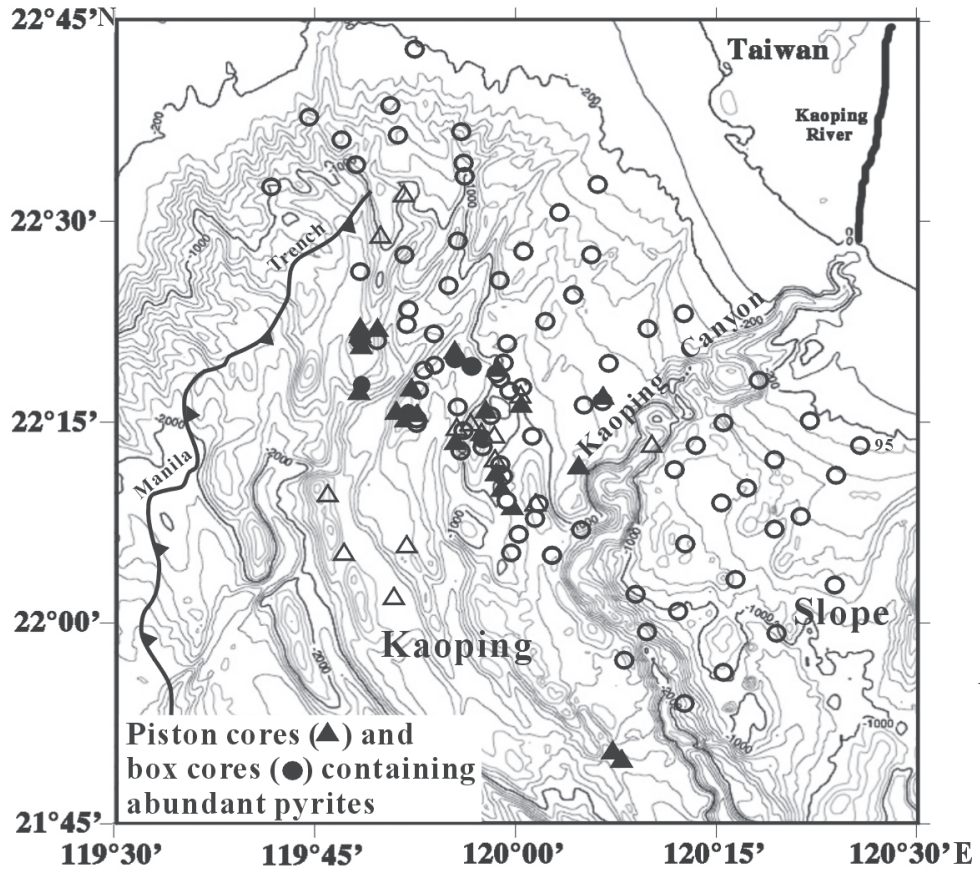

Fig. 9. Sites with common to abundant pyrite tubes in sediments at various horizons of box cores $(\bullet)$ and piston cores $(\boldsymbol{\Delta})$. 


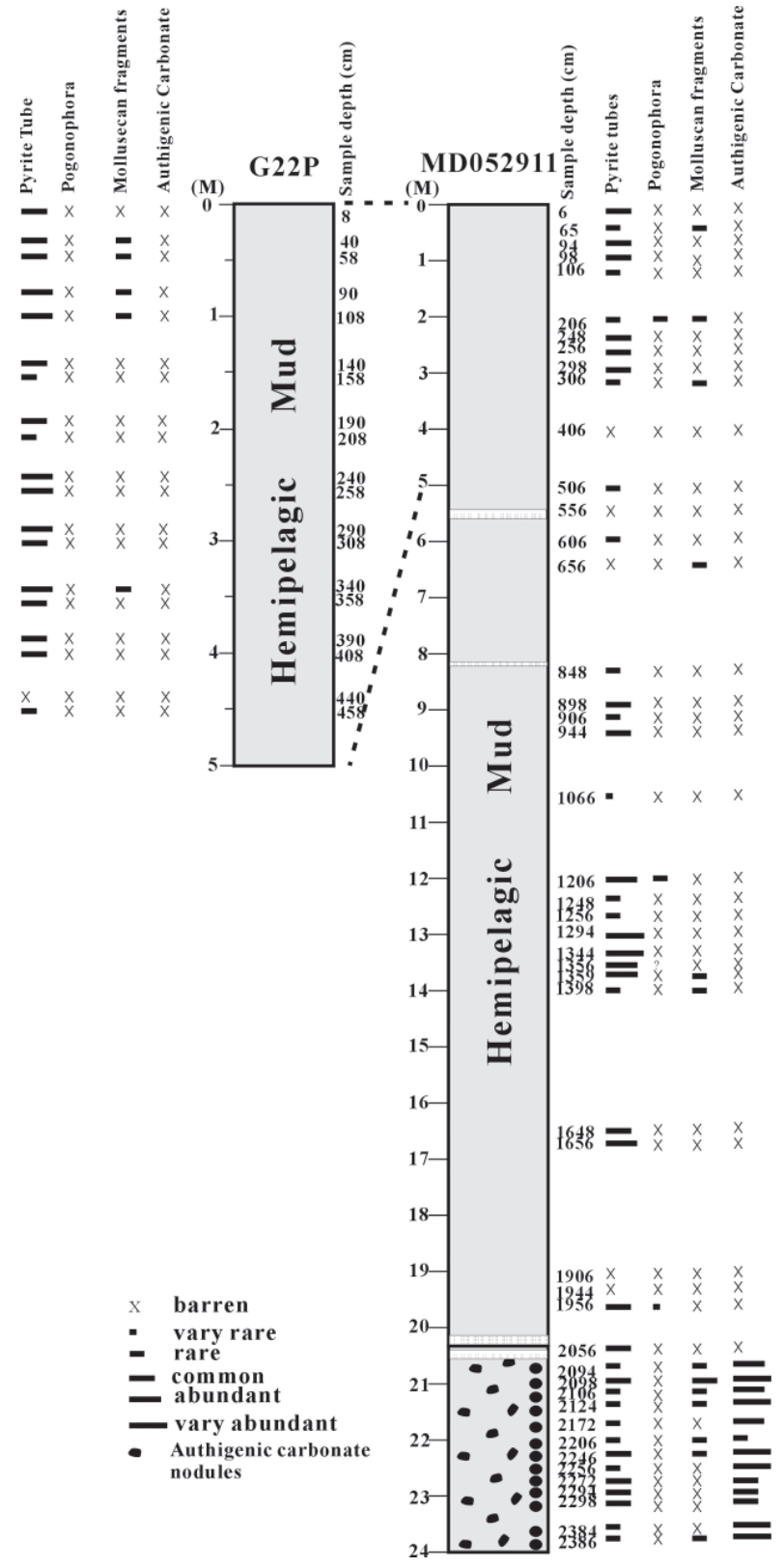

Fig. 10. Geological characterization of the giant piston core MD052911 and the box core G22. Both cores were collected from the same locality by $R / V$ Marion Dufiense and R/V Ocean Research I, respectively. The short core G22 represents only the upper 5 meter of core MD052911. Both cores contain abundant pyrite tubes, while authigenic carbonate nodules occurs in $20-25 \mathrm{~m}$ in core MD052911. 


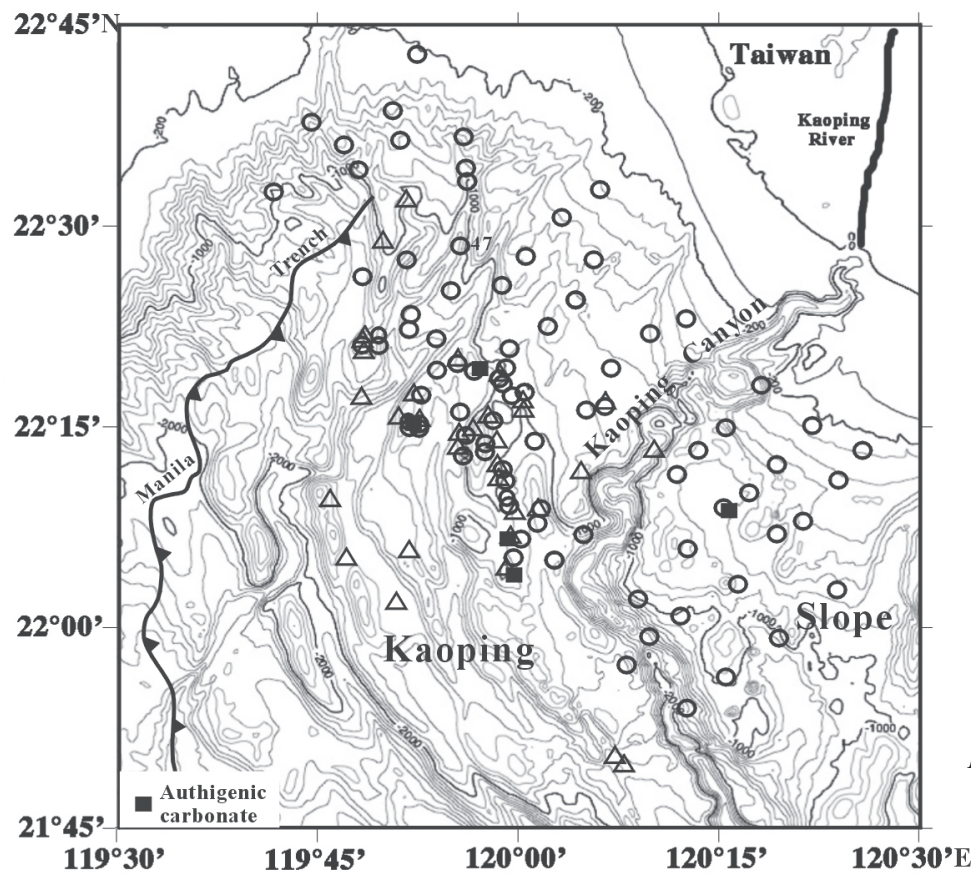

Fig. 11. Distribution of authigenic carbonate $(\boldsymbol{\square})$ in studied cores.

\section{DISCUSSION: POTENTIAL SITES OF COLD SEEPS IN SYN-COLLISION AC- CRETIONARY PRISM OFF SW TAIWAN}

Occurrences of pogonophoran/vestimentiferan tubeworm remains, elongated pyrite tubes and authigenic carbonate nodules could all be used to some extent to infer cold seeps on the ocean floor. Yet, their distribution patterns vary. In the surface sediments, occurrences of pogonophoran tubeworm remains (Fig. 6) and elongated pyrite tubes (Fig. 8) have similar distribution patterns and water depth ranges $(800-1500 \mathrm{~m})$. However, pogonophoran tubeworms with chitin are hardly preserved in sediments after a long history of burial, and their remains are not abundant in sediments except for samples in core G24 (Fig. 3e). In comparison, elongated pyrite tubes are much more abundant in sediments (Fig. 9). As in the situation for the authigenic carbonate nodules, the cores with abundant elongated pyrite tubes distribute mainly in water depths of $1000-1500$ m, especially in the area west of Kaoping Canyon off SW Taiwan (Figs. 9, 11). Although the number of locations with authigenic carbonates is fewer than that with pyrite tubes, each sample with authigenic carbonates always contains abundant elongated pyrite tubes (Fig. 10). We use the occurrence and distribution patterns of tubeworms, 

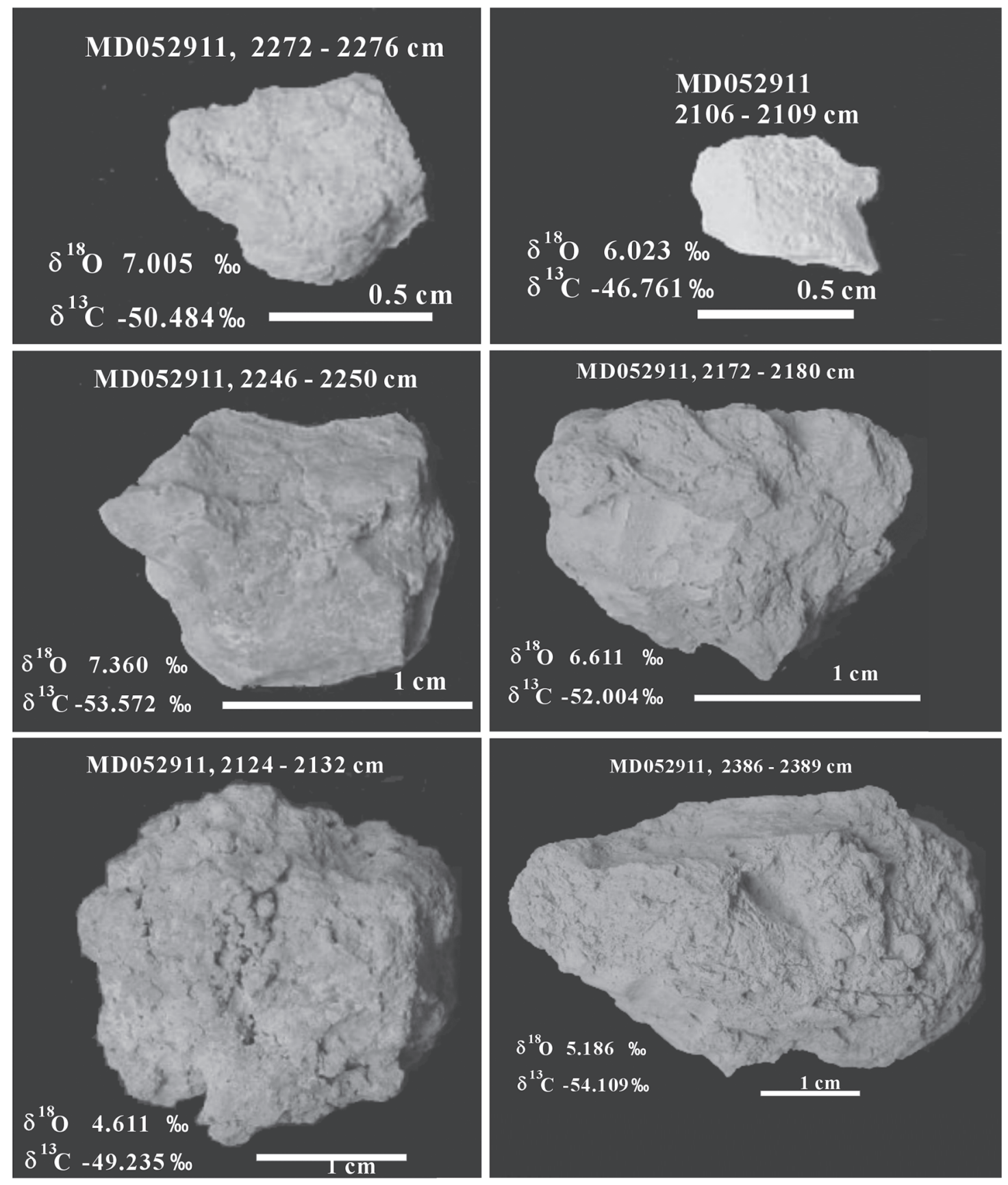

Fig. 12. Authigenic carbonate nodules recovered from core MD052911 and their carbon and oxygen isotope values (also see Table 2). 
Table 2. Locations and carbon isotope values of cores with authigenic carbonate nodules.

\begin{tabular}{|c|c|c|c|c|c|c|c|}
\hline Sample & $\begin{array}{c}\text { Latitude } \\
\text { (N) }\end{array}$ & $\begin{array}{c}\text { Longitude } \\
\text { (E) }\end{array}$ & $\begin{array}{c}\text { Water } \\
\text { Depth } \\
\text { (m) }\end{array}$ & Core length & $\begin{array}{l}\text { Carbonate } \\
\text { Sample depth }\end{array}$ & $\begin{array}{l}\delta 13 C \\
(\mathrm{PDB})\end{array}$ & $\begin{array}{r}\delta 180 \\
\text { (PDB) }\end{array}$ \\
\hline GH-21(T8-P) & $22^{\circ} 04.48^{\prime}$ & $119^{\circ} 58.76$ & 930 & $\begin{array}{l}\text { Core } \\
\text { top }\end{array}$ & $\begin{array}{l}\text { Only core } \\
\text { catcher }\end{array}$ & -48.067 & 7.448 \\
\hline GH-21(T8-P) & $22^{\circ} 04.48^{\prime}$ & $119^{\circ} 58.76$ & 930 & $\begin{array}{l}\text { Core } \\
\text { top }\end{array}$ & $\begin{array}{l}\text { Only core } \\
\text { catcher }\end{array}$ & -48.067 & 7.449 \\
\hline GH-16(T6-P) & $22^{\circ} 06.69^{\prime}$ & $119^{\circ} 59.12$ & 1019 & 260 & $13-18 \mathrm{~cm}$ & -53.485 & 4.681 \\
\hline “ & “ & “ & “ & “" & $90-95 \mathrm{~cm}$ & -57.606 & 5.470 \\
\hline OR II $1230 \quad 108 \mathrm{G}$ & $22^{\circ} 09.053^{\prime}$ & $120^{\circ} 16.867$ & 772 & $27 \mathrm{~cm}$ & Surface & -37.509 & 4.673 \\
\hline “ & “ & “ & “ & “ & Surface & -35.737 & 5.019 \\
\hline “ & “. & “ & “ & “ & $2-4 \mathrm{~cm}$ & -36.623 & 4.846 \\
\hline G14-BOX & $22^{\circ} 18.68^{\prime}$ & $119^{\circ} 58.72$ & 1052 & $20 \mathrm{~cm}$ & $6 \sim 8 \mathrm{~cm}$ & -43.058 & 2.376 \\
\hline MD 052911 & $22^{\circ} 15.61^{\prime}$ & $119^{\circ} 51.08$ & 1076 & $2389 \mathrm{~cm}$ & 2094-2096 & -53.171 & 5.193 \\
\hline “ & “ & “ & “ & “ & $2098-2100$ & -52.560 & 5.636 \\
\hline “ & “ & “ & “ & “ & 2106-2109 & -46.761 & 6.023 \\
\hline “ & “ & “ & “ & “ & 2124-2132 & -49.234 & 4.611 \\
\hline “ & “ & “ & “ & “ & $2172-2180$ & -52.004 & 6.105 \\
\hline “ & “ & “ & “ & “ & $2246-2250$ & -53.572 & 7.36 \\
\hline “ & “ & “ & “ & “ & $2272-2276$ & -50.484 & 7.005 \\
\hline “ & “ & “ & “ & “ & $2386-2389$ & -54.109 & 5.186 \\
\hline
\end{tabular}

elongated pyrite tubes and authigenic carbonate nodules as criteria to assess the potential cold seep sites (three categories) in the area off SW Taiwan (Fig. 13):

1. Category I: low potential cold seep area. This is a region with water depth shallower than $800 \mathrm{~m}$. With the exception of one site, none of the tubeworms, pyrite tubes and authigenic carbonate nodules was found in surface or subsurface sediments of the various cores.

2. Category II: medium potential cold seep area. This is the region with water depths of 800 1500 m east of the Kaoping Canyon. Tubeworms, elongated pyrite tubes and authigenic carbonate nodules have been found in a few sites of this region. 
3. Category III: high potential cold seep area. This is the region with water depths of 800 $1500 \mathrm{~m}$ west of the Kaoping Canyon. Tubeworms, elongated pyrite tubes and authigenic carbonate nodules have been found in many sites of this region.

The high potential cold seep area (Category III) west of the Kaoping Canyon is within the region of typical fault-and-thrust structures. The cold seep sites tend to be located at the anticline hinge zone immediately east of the associated thrust faults in water depths of $800-1500 \mathrm{~m}$ (Fig. 13). Additional pieces of evidence in support of this region as active cold seep sites are the occurrences of distinct BSRs, shallow SMI and high concentration of dissolved methane in the bottom water (Chi et al. 1998; Chuang et al. 2006; Lin et al. 2006; Liu et al. 2006; Yang et al. 2006).

Although the methane seeping in the potential sites of the Kaoping Slope could originate from biogenic source, the preliminary data so far are not sufficient to ascertain the potential occurrence of gas hydrate in the syn-collision accretionary prism Kaoping Slope. More investigations are needed in the near future to evaluate that potential: side scan sonar images, camera-guided in situ sampling and seafloor images by remotely operated vehicles and biological study on the chemosynthetic community associated with methane venting.

\section{CONCLUSIONS}

The potential locations of active cold seep sites in the syn-collision accretionary prism Kaoping Slope off SW Taiwan have been evaluated by three criteria: occurrences of pogonopho-

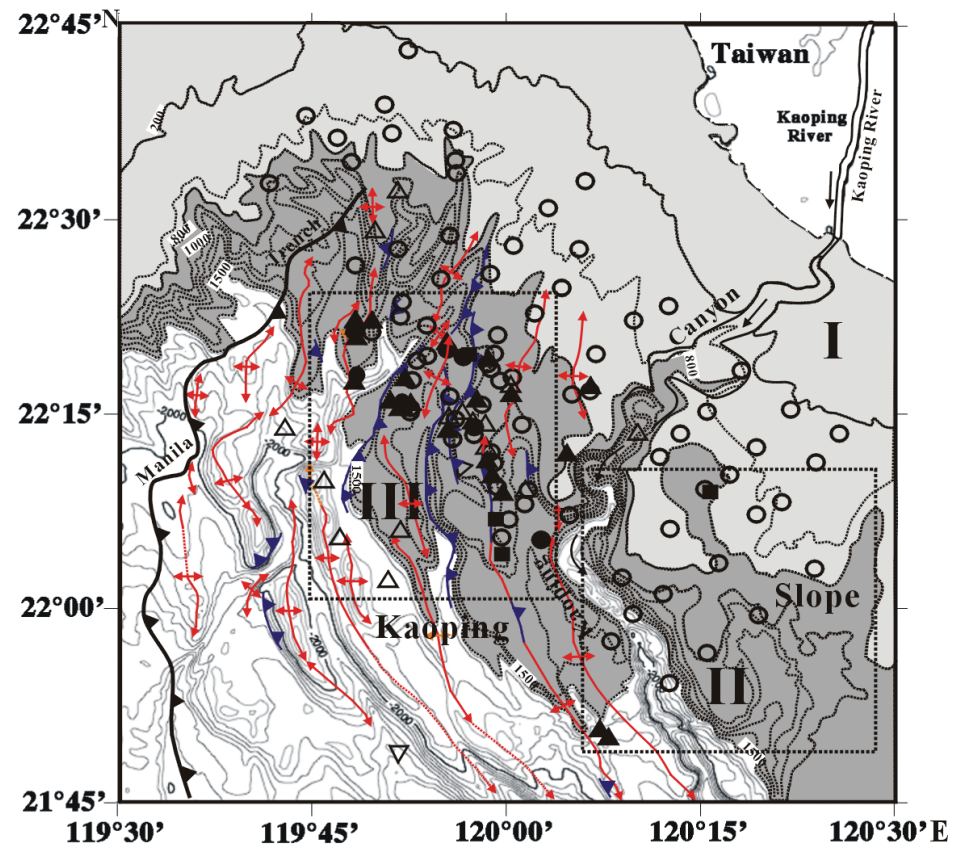

Fig. 13. Preliminary classification of the potential of active cold seep sites in the syn-collision accretionary prism Kaoping Slope off SW Taiwan: (I) low potential; (II) medium potential; and (III) high potential. 
ran tubeworms, elongated pyrite tubes and authigenic carbonates with depleted carbon isotope values. At least two species of Pogonophora tubeworms are found in the study area in water depths of $800-1500 \mathrm{~m}$. The porous and elongated pyrite tubes are commonly observed in surface and core sediments, suggesting the existence of local reducing environment although the bottom water is aerobic. Authigenic carbonate nodules with depleted carbon isotope (-54 $-46 \%$ ) were found at 5 localities, suggesting active venting. These areas are also characterized by bearing distinct BSRs, shallow SMI and high concentrations of dissolved methane in bottom water. To assess the potential active cold seep sites off SW Taiwan for more detailed studies, the investigated area is classified into three categories: low potential area in water depth less than $800 \mathrm{~m}$, medium potential area with water depths of $800-1500 \mathrm{~m}$ east of the Kaoping Canyon, and high potential area with water depths of $800-1500 \mathrm{~m}$ west of the Kaoping Canyon. The high potential active cold seeps are located in several anticline hinge zones immediately east of thrust faults in the frontal accretionary prism Kaoping Slope with typical fault-and-thrust structures east of the Manila Trench off SW Taiwan.

Acknowledgments We appreciate valuable discussions with C. S. Liu, T. F Yang, S. Lin of the National Taiwan University and B. C. Yao, Y. Huang of the Guangzhou Marine Geological Survey during this study. The study was financially supported by the Central Geological Survey, MOEA, and Research Center of Ocean Environment and Technology, NCKU, and National Science Council (NSC94-2116-M006-005) to C. Y. Huang. Support for M. Zhao was provided by Tongji University "985 Project".

\section{REFERENCES}

Boetius, A., and E. Suess, 2004: Hydrate Ridge: a natural laboratory for the study of microbial life fueled by methane from near-surface gas hydrates. Chem. Geol., 205, 291-310.

Borowski, W. S., C. K. Paull, and W. Ussler III, 1999: Global and local variations of interstitial sulfate gradients in deep-water, continental margin sediments: sensitivity to underlying methane and gas hydrates. Mar. Geol., 159, 131-154.

Chen, D. F., Y. Y. Huang, X. L. Yuan, and L. M. Cathles III, 2005: Seep carbonates and preserved methane oxidizing archaea and sulfate reducing bacteria fossils suggest recent gas venting on the seafloor in the Northeastern South China Sea. Mar. Petrol. Geol., 22, 613-621.

Chi, W. C., D. L. Reed, C. S. Liu, and N. Lundberg, 1998: Distribution of the bottom simulating reflector in the offshore Taiwan collision zone. Terr. Atmos. Ocean. Sci., 9, 779-793.

Chiu, J. K., W. H. Tseng, and C. S. Liu, 2006: Distribution of gassy sediments and mud volcanoes offshore southwestern Taiwan. Terr. Atmos. Ocean. Sci., 17, 703-722.

Chow, J., J. S. Lee, R. Sun, C. S. Liu, and N. Lundberg, 2000: Characteristics of the bottom simulating reflectors near mud diapirs: offshore southwestern Taiwan. Geo-Mar. Lett., 20, 3-9.

Chuang, P. C., T. F. Yang, S. Lin, H. F. Lee, T. F. Lan, W. L. Hong, C. S. Liu, J. C. Chen, and Y. Wang, 2006: Extremely high methane concentration in bottom water and cored sediments from offshore southwestern Taiwan. Terr. Atmos. Ocean. Sci., 17, 903-920. 
Dallimore, S. R., T. S. Collett, and T. Uchida, 1999: Scientific results from JAPEX/JNOC/ GSC Mallik 2L-38 gas hydrate research well, Mackenzie Delta, Northwest Territories. Can. Geol. Surv. Bull., 544, 11-17.

Dando, P. R., I. Bussmann, S. J. Niven, S. C. M. O“Hara, R. Schmaljohann, and L. J. Taylor, 1994: A methane seep area in the Skagerrak, the habitat of the pogonophore Siboglinum poseidoni and bivalve mollusk Thyasira sarsi. Mar. Ecol.Prog. Ser., 107, 157-167.

Dimitrov, L. I., 2002: Mud volcanoes - the most important pathway for degassing deeply buried sediments. Earth-Sci. Rev., 59, 49-76.

Felbeck, H., 1981: Chemoautotrophic potential of the hydrothermal vent tube worm Riftia pachytila Jones (Vestimentifera). Science, 213, 336-338.

Fleischer, P., T. H. Orsi, M. D. Richardson, and A. L. Anderson, 2001: Distribution of free gas in marine sediments: a global overview. Geo-Mar. Lett., 21, 103-122.

Gay, A., M. Lopez, P. Cochonat, M. Séramme, D. Levaché, and G. Sermondadaz, 2006: Isolated seafloor pockmarks linked to BSRs, fluid chimneys, polygonal faults and stacked Oliogocene-Miocene turbiditic palaeochannels in the Loer Congo Basin. Mar. Geol., 226, 25-40.

Goedert, J. L., J. Peckmann, and J. Reitner, 2000: Worm tubes in an allochthonous cold-seep carbonate from lower Oligocene rocks of western Washington. J. Paleontol., 74, 992-999.

Hathaway, J. C., and E. T. Degens, 1969 Methane-derived carbonates of Pleistocene age. Science, 165, 690-692.

Hill, T. M., J. P. Kennett, and D. L. Valentine, 2004: Isotopic evidence for the incorporation of methane-derived carbon into foraminifera from modern methane seeps, Hydrate Ridge, Northeast Pacific. Geochim. Cosmochim. Acta, 68, 4619-4627.

Huang, C. Y., W. Y. Wu, C. P. Chang, S. Tsao, P. B. Yuan, C. W. Lin, and K. Y. Xia, 1997: Evolution of the pre-collision accretionary prism in the arc-continent collision terrane of Taiwan. Tectonophysics, 281, 31-51.

Huang, C. Y., P. B. Yuan, C. W. Lin, T. K. Wang, and C. P. Chang, 2000: Geodynamic processes of Taiwan arc-continent collision and comparison with analogs in Timor, Papua New Guinea, Urals and Corsica. Tectonophysics, 325, 1-21.

Huang, C. Y., P. B. Yuan, and S. J. Tsao, 2006: Temporal and spatial records of active arccontinent collision in Taiwan: a synthesis. Bull. Geol. Soc. Am., 118, 274-288.

Ivanov. A. V., 1963: Pogonophora. Academic press, London, 469 pp.

Iizuka, Y., P. Bellwood, H. C. Hung, and E. Z. Dizon, 2005: A Non-Destructive mineralogical Study of Nephritic Artifacts from Itbayat Island, Batanes, northern Philippines. J. Austronesian Stud., 1, 83-108.

Jones, M. L., 1985: On the Vestimentifera, new Phylum: six new species, and other taxa, from hydrothermal vents and elsewhere. Bull. Biol. Soc. Wash., 6, 117-158.

Kastner, M., 2001: Gas hydrates in convergent margins: Formation, occurrence, geochemistry, and global significance. In: Paull, C. K., and W. P. Dillon, (Eds.), Natural gas hydrate occurrence, distribution, and detection, AGU Geophys. Monogr., 124, 67-86.

Katz, M. E., D. K. Pak, G. R. Dickens, and K. G. Miller, 1999: The source and fate of massive carbon input during the latest Paleocene thermal maximum. Science, 286, 1531-1533.

Kemp, D. B., A. L. Coe, A. S. Cohen, and L. Schwark, 2005: Astronomical pacing of methane release in the Early Jurassic Period. Nature, 437, 396-399. 
Kennicutt II, M. C., J. M. Brooks, R. R. Bidigare, R. R. Fay, T. L. Wade, and T. J. McDonald, 1985: Vent-type taxa in a hydrocarbon seep region on the Louisiana slope. Nature, 317, 351-353.

Kohn, M. J., L. R. Riciputi, D. Stakes, and D. L. Orange, 1998: Sulfur isotope variability in biogenic pyrite: reflections of heterogeneous bacterial colonization? Am. Mineral., 83, 1454-1468.

Kulm, L. D., E. Suess, J. C. Moore, B. Carspm, B. T. Lewis, S. D. Ritger, D. C. Kadko, T. M. Thornburg, R. W. Embley, W. D. Rugh, G. J. Massoth, M. G. Langseth, G. R. Cochrane, and R. L. Scamman, 1986: Oregon subduction zone: venting, fauna and carbonates. Science, 231, 561-566.

Kvenvolden, K., and T. D. Lorenson, 2001: The global occurrence of natural gas hydrate. In: Paull, C. K., and W. P. Dillon (Eds.), Natural gas hydrates: occurrence, distribution, and detection, AGU Geophys. Monogr., 124, 3-18.

Lein, A. Y., 2004: Authigenic carbonate formation in the ocean. Lithol. Miner. Resour., 39, 1-30.

Lin, H. L., L. W. Wang, C. H. Wang, and G. C. Gong, 1999: Vertical distribution of $\delta^{13}$ C of dissolved inorganic carbon in the northeastern South China Sea. Deep-Sea Res. I, 46, 757-775.

Lin, S., W. C. Hsieh, Y. C. Lim, T. F. Yang, C. S. Liu, and Y. Wang, 2006: Methane migration and its influence on sulfate reduction in the Good Weather Ridge region, South China Sea continental margin sediments. Terr. Atmos. Ocean. Sci., 17, 883-902.

Liu, C. S., N. Lundberg, D. L. Reed, and Y. L. Huang, 1993: Morphological and seismic characteristics of the Kaoping Submarine Canyon. Mar. Geol., 111, 93-108.

Liu, C. S., S. Y. Liu, S. E. Lallemand, N. Lundberg, and D. L. Reed, 1998: Digital elevation model offshore Taiwan and its tectonic implications. Terr. Atmos. Ocean. Sci., 9, 705-738.

Liu, C. S., P. Schnürle, Y. Wang, S. H. Chung, S. C. Chen, and T. H. Hsiuan, 2006: Distribution and characters of gas hydrate offshore of southwestern Taiwan. Terr. Atmos. Ocean. Sci., 17, 615-644.

Milkov, A. V., 2000: Worldwide distribution of submarine mud volcanoes and associated gas hydrates. Mar. Geol., 167, 29-42.

Paull, C. K., A. J. T. Jull, L. J. Toolin, and T. Linick, 1985: Stable isotopic evidence for chemosynthesis in an abyssal seep community. Nature, 317, 709-711.

Paull, C. K., J. P. Chanton, A. C. Neumann, J. A. Coston, C. S. Martens, and W. Showers, 1992: indicators of methane-derived carbonates and chemosynthetic organic carbon deposits: Examples from the Florida Escarpment. Palaios, 7, 361-375.

Reed, D. L., N. Lundberg, C. S. Liu, and B. Y. Luo, 1992: Structural relations along the margins of the offshore Taiwan accretionary wedge: implications for accretion and crustal kinematics. Acta Geol. Taiwan., 30, 105-122.

Riedel, M., I. Novosel, G. D. Spence, R. D. Hyndman, R. N. Chapman, R. C. Solem, and T. Lewis, 2006: Geophysical and geochemical signatures associated with gas hydraterelated venting in the northern Cascadia margin. Bull. Geol. Soc. Am., 118, 23-38.

Roberts, H., 2001: Fluid and gas expulsion on the northern Gulf of Mexico continental slope: Mud-prone to mineral - prone responses. In: Paull, C. K., and W. P. Dillon (Eds), Natural gas Hydrate Occurrence, Distribution, and Detection, AGU Geophys. Monogr., $124,145-161$. 
Schmaljohann, R., and H. J. Flügel, 1987: Methane-oxidizing bacteria in Pogonophora. Sarsia, 72, 91-98.

Scott, K. M., and C. R. Fisher, 1995: Physiological ecology of sulfide metabolism in hydrothermal vent and cold seep vesicomyid clam and vestimentiferan tube worms. Am. Zool., 35, 102-111.

Shih, T. T., 1967: A survey of the active mud volcanoes in Taiwan and a study of their types and the character of the mud. Petrol. Geol. Taiwan, 5, 259-311.

Sibuet, M., and K. Olu, 1998: Biogeography, biodiversity and fluid dependence of deep-sea cold-seep communities at active and passive margins. Deep-Sea Res. II, 45, 517-567.

Southward, A. J., E. C. Southward, P. R. Dando, G. H. Rau, H. Felbeck, and F. Flügel, 1981: Bacterial symbionts and low ${ }^{13} \mathrm{C}^{12} \mathrm{C}^{-1}$ ratios in tissues of Pogonophora indicate unusual nutrition and metabolism. Nature, 293, 616-620.

Suess, E., M. E. Torres, G. Bohrmann, R. W. Collier, D. Rickert, C. Goldfinger, P. Linke, A. Heuser, H. Sahling, K. Heeschen, C. Jung, K. Nakamura, J. Greinert, P. Pfannkuche, A. Trehu, G. Klinkhammer, M. J. Whiticar, A. Eisenhauser, B. Teichert, and M. Elvert, 2001: Sea floor methane hydrate at Hydrate Ridge, Cascadia margin. In: Paull, C. K., and W. P. Dillon (Eds.), Natural Gas Hydrate Occurrence, Distribution, and Detection, AGU Geophys. Monogr., 124, 87-98.

Sun, C. S., and C. S. Liu, 1993: Mud diapirs and submarine channel deposits in offshore Kaohsiung-Hengchun, southwestern Taiwan. Petrol. Geol. Taiwan, 28, 1-14.

Valentine, D. L., 2002: Biochemistry and microbial ecology of methane oxidation in anoxic environments: a review. Antonie van Leeuwenhoek, 81, 271-282.

Vogt, P. R., J. Gardner, and K. Crane, 1999: The Norwegian-Barents-Svalbard (NBS) continental margin: introducing a natural laboratory of mass wasting, hydrates, and ascent of sediment, pore water, and methane. Geo-Mar. Lett., 19, 2-21.

Yang, T. F., G. H. Yeh, C. C. Fu, C. C. Wang, T. F. Lan, H. F. Lee, C. H. Chen, and V. Walia, and Q. C. Sung, 2004: Composition and exhalation flux of gases from mud volcanoes in Taiwan. Environ. Geol., 46, 1003-1011.

Yang, T. F., P. C. Chuang, S. Lin, J. C. Chen, Y. Wang, and S. H. Chung, 2006: Methane venting in gas hydrate potential area offshore of SW Taiwan: evidence of gas analysis of water column samples. Terr. Atmos. Ocean. Sci., 17, 933-950.

Huang, C. Y., C. W. Chien, M. Zhao, H. C. Li, and Y. Iizuka, 2006: Geological study of active cold seeps in the syn-collision accretionary prism Kaoping slope off SW Taiwan. Terr. Atmos. Ocean. Sci., 17, 679-702. 